\title{
Hereditary Colorectal Cancer (CRC) Program in Latvia
}

\author{
Arvids Irmejs', Andris Gardovskis', Viktors Borosenko', Marianna Bitina', Diana Aigare', \\ Grzegorz Kurzawski', Janina Suchy', Bohdan Górski', Janis Gardovskis'
}

'Hereditary Cancer Institute, Riga Stradins University, Riga, Latvia; ${ }^{2}$ International Hereditary Cancer Center, Pomeranian Medical University, Szczecin Poland

Key words: hereditary, colorectal cancer

Corresponding author: Arvids Irmejs, Hereditary Cancer Institute of Riga Stradins University, Dzirciema str. 16, LV 1007, Riga, Latvia.Phone: +37 19171604; fax:+37 17069973; e-mail: irmejs@dr.lv

\begin{abstract}
Introduction. The aim of the study is to evaluate the incidence and phenotype - genotype characteristics of hereditary colorectal cancer syndromes in Latvia in order to develop the basis of clinical management for patients and their relatives affected by these syndromes. Material and methods. From 02/1999-09/2002 in several hospitals in Latvia cancer family histories were collected from 865 patients with CRC. In families suspected of having a history consistent with a hereditary colorectal cancer syndrome, DNA testing for MLH1, MSH2 and MSH6 genes was performed. In addition immunohistochemical $(\mathrm{IH})$ examination of the normal and cancer tissue from large bowel tumors for MSH2 and MSH6 protein expression was performed prior to DNA analysis. Results. From the 865 CRC cases only 3 (0.35\%) pedigrees fulfilled the Amsterdam II criteria of Hereditary Nonpolyposis Colorectal Cancer (HNPCC) and 15 cases (1.73\%) were suspected of HNPCC. In 69 cases (8\%) with a cancer family aggregation (CFA) were identified. Thus far $27 \mathrm{IH}$ analyses have been performed and in 3 cancers homogenous lack of MSH2 or MSH6 protein expression was found. In one of these cases a mutation in MSH6 was identified. In 18 patients suspected of HNPCC or of matching the Amsterdam II criteria, denaturing high performance liquid chromatography (DHPLC) followed by DNA sequencing of any heteroduplexes of the 35 exons comprising both MLH1 and MSH2 was performed revealing 3 mutations.

For all of kindreds diagnosed definitively or with a high probability of being an HNPCC family appropriate recommendations concerning prophylactic measures, surveillance and treatment were provided in written form. Conclusions. Existing pedigree/clinical data suggest that in Latvia the frequency of HNPCC is around $2 \%$ of consecutive colorectal cancer patients. It is crucial that genetic counseling is an integral part of cancer family syndrome management.
\end{abstract}

\section{Introduction}

During the last decade dramatic changes have taken place in the diagnosis and management of familial/hereditary colorectal cancer syndromes. New developments are offering possibilities of early cancer detection, improvements in treatment and preventive measures for the affected and persons at risk of disease. Hereditary cancer management has developed as an essential part of modern oncology treatment and current practice reveals the importance of cancer genetic services in providing the best care for hereditary cancer syndrome patients.
Latvia is an East European country located in the Baltic region with approximately 2.4 million of inhabitants. In the year 2002 there were 8977 new cancer cases detected in Latvia, including 926 colorectal cancer cases. From all newly diagnosed cancers only $17.4 \%$ were detected in stage l, and $22.9 \%$ in stage of the II disease. According to epidemiological data available for familial colorectal cancer, one would expect somewhere in between 90 and 130 familial cases in Latvia annually. From this estimate, 20-60 of them are most likely to be associated with hereditary condition (either HNPCC or FAP). Detection and appropriate management of patients affected with disease or those 
Table 1. Diagnostic criteria for hereditary colorectal cancer syndromes

\begin{tabular}{|c|c|c|}
\hline No. & Hereditary syndrome & Diagnostic criteria \\
\hline 1. & Definitive HNPCC $[2,3,4]$ & $\begin{array}{l}\text { Amsterdam II criteria: } \\
\text { 1) at least } 3 \text { relatives affected by HNPCC associated cancer (colorectal, endometrial, small } \\
\text { bowel, ureter, renal pelvis); at least one should be the first degree relative of the other two; } \\
\text { 2) at least two successive generations should be affected; } \\
\text { 3) at least one cancer should be diagnosed before the age of 50; } \\
\text { 4) familial adenomatos polyposis (FAP) should be excluded; } \\
\text { 5) tumors should be verified by pathological examination }\end{array}$ \\
\hline 2. & Late onset HNPCC & Amsterdam II criteria without age limitation \\
\hline 3. & Suspected HNPCC $[5,6]$ & $\begin{array}{l}\text { 1) at least } 2 \text { first degree relatives with HNPCC associated cancer } \\
\text { (colorectal, endometrial, small bowel, urinary tract); } \\
\text { 2) at least one cancer should be diagnosed before the age of } 50\end{array}$ \\
\hline 4. & $\begin{array}{l}\text { Familial colorectal } \\
\text { cancer (FCC) [7] }\end{array}$ & $\begin{array}{l}\text { 1) Colorectal cancer in at least } 2 \text { first or second degree relatives; } \\
\text { 2) colorectal cancer diagnosed at relatively young age; } \\
\text { 3) HNPCC and FAP should be excluded }\end{array}$ \\
\hline 5. & $\begin{array}{l}\text { Cancer familial } \\
\text { aggregation (CFA) }\end{array}$ & at least 3 first degree blood relatives with malignancy of any localization \\
\hline
\end{tabular}

with an increased risk of developing it would provide a considerable improvement in oncology care in Latvia.

Active investigations and research into hereditary cancers in Latvia began almost ten years ago [1]. However, clinical work on hereditary cancer syndromes became more widely accepted in 1998, when the Department of Surgery, Riga Stradins University was invited to participate in the European Commission funded Copernicus multicenter project entitled: Phenotype - genotype correlations in HNPCC and MENI (IC15 - CT98 - 0305). Since its success was readily apparent the international collaboration was extended within the EC $5^{\text {th }}$ framework programme - Development of network of cancer family syndrome registries in Eastern Europe (QLRI-CT-1999-00063). During the $2^{\text {nd }}$ year of this project, the Hereditary Cancer Institute of Riga Stradins University was established. The main aim of this institution is to study the hereditary cancer syndromes in the population of Latvia and to introduce the obtained knowledge into clinical practice.

In the following article we would like to report results of this study, which is taking place in the framework of the hereditary colorectal cancer program in Latvia. The aim of the study is to evaluate the incidence and phenotype/genotype characteristics of hereditary colorectal cancer syndromes in Latvia in order to develop a rational basis for the clinical management of patients and their relatives affected by these syndromes.

\section{Methods}

From February 1999 to September 2002 cancer family histories were collected from 865 patients with colorectal cancer in the largest oncology hospitals of Latvia. Patients completed questionnaires that included questions, which asked: Had your relatives (father, mother, grandparents, siblings, children, grandchildren, aunts, uncles) been diagnosed with any tumor? What was the localization of the tumor? At what age was the tumor detected?

Criteria applied for the diagnosis of hereditary colorectal cancers are summarized in Table 1.

In individuals from families matching criteria for hereditary colorectal cancer syndromes, genetic testing for MLH1, MSH2 and MSH6 mutations using DHPLC and concomitant DNA sequencing of all heteroduplexes was performed [8-13] after obtaining written informed consent from each patient. If material was available immunohistochemical examination of the normal and cancer tissue from large bowel for MSH2 and MSH6 protein expression was performed before DNA sequencing. The Ethics Commission, Riga Stradins University, accepted the protocol for the study.

\section{Results}

From the 865 colorectal cancer patients 402 (46.47\%) cases did not report any malignancy in their families. In 463 (53.53\%) colorectal cancer cases there was at least one malignancy among blood relatives. Only $3(0.35 \%)$ pedigrees fulfilled the Amsterdam II criteria. Unfortunately, histopathological confirmation of cancer in affected family members of those 3 pedigrees was not possible. One patient (0.12\%) fulfilled late onset HNPCC criteria. Fourteen individuals (1.62\%) matched the criteria of suspected HNPCC. In 41 
(4.74\%) patients the suspicion of familial colorectal cancer was diagnosed. In 69 cases (8\%) CFA was detected. Currently, 27 immunohistochemical examinations have been performed. In 3 tumors MSH2 or MSH6 protein expression was homogenously negative suggesting a germline mutation in either one of these genes. In 1 of these cases mutation in MSH6 gene (exon 4, 1815-1816delTA) was detected. The pedigree of this family matched late onset HNPCC criteria. In an additional 25 patients DNA sequencing of $\mathrm{MLH} 1$ and $\mathrm{MSH} 2$ genes was performed. One MLH1 and two MSH2 mutations were identified. The pedigree of the family with a mutation in MLH1 (ex12 (G/A 1409+1 out of frame del) is shown on Fig. 1. Due to lack of any medical confirmation for cancer diagnosis in the probands' relatives this pedigree was classified as belonging to the CFA syndrome.

Two hMSH2 mutations were detected in ex3 (C508T; Gln170Stop) and ex12 (c.1786delAAT; 596 delAsn) respectively. Both families fulfilled the suspected HNPCC criteria.

For all of the families with HNPCC diagnosed by the Amsterdam II criteria or within high probability group, appropriate recommendations concerning prophylactic measures, surveillance and treatment were elaborated and transmitted in written form.

\section{Discussion}

Every year in Latvia approximately 900 new colorectal cancer cases are diagnosed. During our study period we have collected cancer family histories from about $30 \%$ of the total number of cases. The initial intention was to collect cancer family histories from all consecutive cases in the principal oncology hospitals of Latvia, but due to a variety of different reasons (patient's refusals, limited capacities of research group etc.) this was not possible.

Our group of colorectal cancer patients is, however, comparable to the total group of newly diagnosed colorectal cancer patients as far as age, gender, nationality, place of residence and clinical stage are concerned. Therefore our colorectal cancer group can be considered as representative for all newly diagnosed colorectal cancer patients in Latvia and can be used in pilot epidemiological studies. On the basis of 865 cancer family histories the incidence of HNPCC in the population of Latvia is somewhere between $0.5-2 \%$ of all colorectal cancers. According to several other studies, the incidence of HNPCC varies considerably from $1 \%$ to $10 \%$ of all colorectal cancers in different populations and ethnic groups [6, 9, 14-19]. It appears that clinical incidence of HNPCC in Latvia is one of the

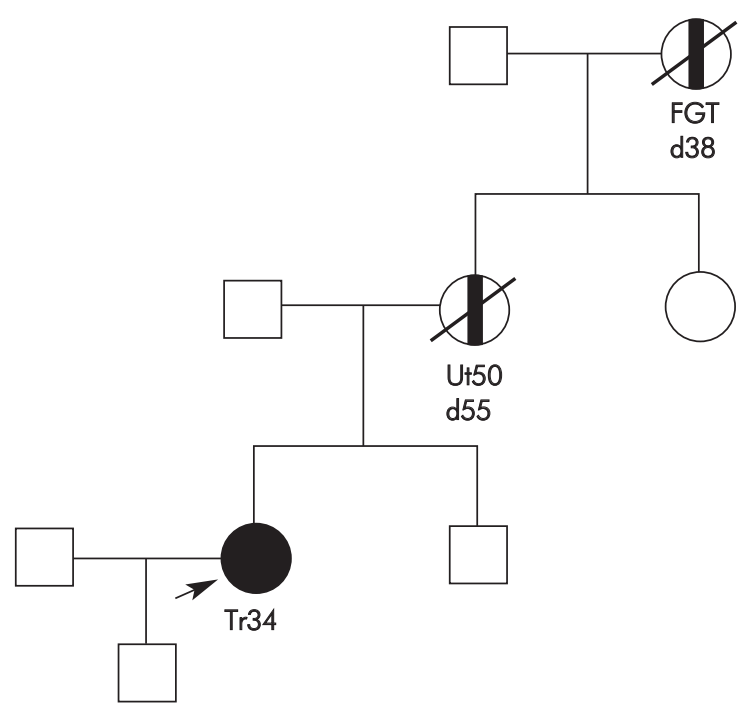

Fig. 1. Pedigree of the MLH1 (c. 1409+1G/A) family; Tr, transversum; Ut, uterus; FGT, female genital tract; The numbers following abbreviations indicate the age of cancer diagnosis; Arrow indicates the proband

lowest reported. This estimate is supported by molecular evidence where two MSH2 and only one of each $\mathrm{MLH1} / \mathrm{MSH} 6$ mutations were detected. There is no data available about the incidence of hereditary colorectal cancer syndromes in neighboring countries like Estonia and Lithuania. However there are published data on 3 and 6 families, respectively, which fulfills the Amsterdam II criteria or suspected HNPCC criteria from Estonia and Lithuania. In 2 Lithuanian families and one Estonian family mutations in $\mathrm{MLH} 1$ and $\mathrm{MSH} 2$ genes were detected [5]. Results of a prospective multicenter epidemiological study of HNPCC in Finland reveals that the frequency of hereditary nonpolyposis colorectal cancer is between $0.7-2.4 \%$, which is very similar to the frequency observed in our study [20].

Unfortunately, we cannot exclude bias related to the poor reliability of collected pedigree information. Many families have small numbers of relatives and they have very poor medical information about one another for several different historical reasons.

None of the first four mutations identified in the Latvian population were similar to the founder mutations identified in Lithuania or Poland [5], however, the number of mutations currently detected does not allow for any ultimate conclusion.

In Table 2 the mutation rate and clinical HNPCC detection rate in specific age groups is presented. From 4 mutations 2 were identified in probands in an age group between 30-39 years, which corresponds to a younger age of HNPCC diagnosis [21]. The only HNPCC family (with rare mutation in MSH2 gene) in 
Table 2. Mutation detection rate in specific age ranges

\begin{tabular}{|c|c|c|c|c|c|}
\hline $\begin{array}{l}\text { Age range } \\
\text { of colorectal } \\
\text { cancer cases }\end{array}$ & $\begin{array}{l}\text { Number } \\
\text { of cases }\end{array}$ & $\begin{array}{c}\text { Percentage } \\
(\%)\end{array}$ & $\begin{array}{l}\text { Mutations } \\
\text { found }\end{array}$ & $\begin{array}{l}\text { Mutation detection } \\
\text { rate in particular } \\
\text { age group (\%) }\end{array}$ & $\begin{array}{l}\text { Definitive } \\
\text { and suspected } \\
\text { HNPCC cases }\end{array}$ \\
\hline-29 & 2 & 0.23 & 0 & 0 & 0 \\
\hline $30-39$ & 11 & 1.27 & 2 & 18.2 & 1 \\
\hline $40-49$ & 38 & 4.49 & 0 & 0 & 3 \\
\hline $50-59$ & 145 & 16.86 & 0 & 0 & 1 \\
\hline $60-69$ & 330 & 38.25 & 1 & 0.3 & 10 \\
\hline $70-79$ & 239 & 27.24 & 1 & 0.4 & 3 \\
\hline $80-89$ & 38 & 4.49 & 0 & 0 & 0 \\
\hline $90-$ & 1 & 0.12 & 0 & 0 & 0 \\
\hline Age unknown & 61 & 7.05 & 0 & 0 & 0 \\
\hline Total & 865 & 100 & 4 & - & 18 \\
\hline
\end{tabular}

Latvia detected by another working group in 1997 was also found through a proband with a CRC diagnosed at the age of 34 . According to the data obtained it is very important to screen actively for hereditary syndromes all colorectal cancer patients in the age group of 30-39 years as the mutation detection rate in our series is relatively high (18.2\%).

\section{Conclusions}

- Development of hereditary colorectal cancer program in Latvia is a result of successful international collaboration in the framework of scientific projects of the European Commission.

- According to cancer family history data and DNA testing results the incidence of HNPCC in Latvia is $2 \%$.

- Genetic counseling should be the integral part of any cancer family syndrome program.

\section{Acknowledgments and affiliation}

Publication supported by EC project no QLRI-CT1999-00063.

Authors thank Prof. J. Lubiński, director of International Hereditary Cancer Center, Pomeranian Medical University, Poland for fruitful collaborative efforts.

\section{References}

1. Csokay B, Tihomirova L, Stengrevics A, Sinicka O, Olah E. Strong founder effects in BRCAl mutation carrier breast cancer patients from Latvia. Mutation in brief no 258, Hum Mutat 1999; 14 (1): 92.
2. Vasen HF, Mecklin JP, Lynch HT. The International Collaborative Group on Hereditary Non-Polyposis Colorectal Cancer(ICGHNPCC). Dis Colon Rectum 1991; 34: 424-5.

3. Park JG, Vasen HF, Park KJ, Peltomaki P, Ponz de Leon M, Rodriguez-Bigas MA, Lubinski J, Beck NE, Bisgaard ML, Miyaki M, Wijnen JT, Baba S, Lynch HT. Suspected hereditary nonpolyposis colorectal cancer: International Collaborative Group on Hereditary Non-Polyposis Colorectal Cancer (ICGHNPCC) criteria and results of genetic diagnosis. Dis Colon Rectum 1999; 42 (6): 710-5.

4. Park JG, Vasen HF, Park YJ, Park KJ, Peltomaki P, de Leon MP, Rodriguez-Bigas MA, Lubinski J, Beck NE, Bisgaard ML, Miyaki M, Wijnen JT, Baba S, Lindblom A, Madlensky L, Lynch HT. Suspected HNPCC and Amsterdam criteria II: evaluation of mutation detection rate, an international collaborative study. Int J Colorectal Dis 2002; 17 (2): 109-14.

5. Kurzawski G, Suchy J, Kladny J, Safranow K, Jakubowska A, Elsakov P, Kucinskas V, Gardovski J, Irmejs A, Sibul H, Huzarski T, Byrski T, Debniak T, Cybulski C, Gronwald J, Oszurek O, Clark J, Gozdz S, Niepsui S, Slomski R, Plawski A, LackaWojciechowska A, Rozmiarek A, Fiszer-Maliszewska L, Bebenek M, Sorokin D, Stawicka M, Godlewski D, Richter P, Brozek I, Wysocka B, Jawien A, Banaszkiewicz Z, Kowalczyk J, Czudowska D, Goretzki PE, Moeslein G, Lubinski J. Germline MSH2 and MLH1 mutational spectrum in HNPCC families from Poland and the Baltic States. J Med Genet 2002; 39 (10): E65.

6. Boesze P, Elsakov P, Foretova L, Gardovskis J, Haites N, Lubinski $J$, Mecklin JP, Moeslein G, Neumann H, Ponder B, Sobol H, Vasen H, Weber W. Progress report of EC project QLRI - 1999 - 00063 Development of network of cancer family syndrome registries in Eastern Europe. Standards of a model registry of cancer family syndromes for Eastern Europe, 2000; www.republika.pl/genetyka/standards.htm

7. Erfelijke tumoren. Richtlijnen voor diagnostiek en preventie. Stichting opsporing erfelijke tumoren\&vereniging klinische genetica nederland werkgroep klinische oncogenetica, 2001.

8. Lynch HT, Smyrk T. Hereditary nonpolyposis colorectal cancer (Lynch syndrome). An updated review. Cancer 1996; 78 (6): 1149. 
9. Lynch HT, Shaw MW, Magnuson CW, Larsen AL, Krush AJ. Hereditary factors in cancer: study of two large midwestern kindreds. Arch Intern Med 1966; 117: 206.

10. Lynch HT, Smyrk TC, Watson P. Genetics, natural history, tumor spectrum, and pathology of hereditary nonpolyposis colorectal cancer: an updated review. Gastroenterology 1993; 104 (5): 1535.

11. Liu B, Parsons R, Papadopoulos N. Analysis of mismatch repair genes in hereditary non-polyposis colorectal cancer patients. Nat Med 1996; 2 (2): 169

12. Peltomaki P, Aaltonen LA. Genetic maping of a locus predisposing to human colorectal cancer. Science 1993; 260: 810 .

13. Liu B, Parsons RE, Hamilton SR. hMSH2 mutations in hereditary nonpolyposis colorectal cancer kindreds. Cancer Res 1994; 54 (17): 4590

14. Watson P, Lynch HT. Extracolonic cancer in hereditary nonpolyposis colorectal cancer. Cancer 1993; 71 (3): 677.

15. Winawer SJ. Colorectal cancer screening: clinical guidelines and rationales. Gatroenterology 1997; 112: 594.

16. Lynch HT, Lemon SJ, Karr B. Etiology, natural history, management and molecular genetics of hereditary nonpolyposis colorectal cancer (Lynch syndromes): genetic counseling implications. Cancer Epidemiol Biomarkers Prev 1997; 6 (12): 987.

17. Lynch HT, Smyrk T, Lynch J. Update on the differential diagnosis, surveillance and management of hereditary non-polyposis colorectal cancer. Eur J Cancer 1995; 31A (7-8): 1039.

18. Lynch HT, de la Chapelle A. Genetic susceptibility to nonpolyposis colorectal cancer. J Med Genet 1999; 36 (1 1): 801.

19. Marra G, Boland CR. Hereditary nonpolyposis colorectal cancer: the syndrome, the genes, and historical perspectives. J Natl Cancer Inst 1995; 87 (15): 1114.

20. Mecklin JP, Jarvinen HJ, Hallikas H, Hiltunen KM, Harkonen N, Kellokumpu I, Laitinen S, Ovaska J, Tulikoura J, et al. Frequency of hereditary nonpolyposis colorectal cancer. A prospective multicenter study in Finland. Dis Colon Rectum 1995; 38 (6): 588-93.

21. Vasen HF, Mecklin JP, Watson P, Utsunomiya J, Bertario L, Lynch $P_{\text {, }}$ Svendsen LB, Cristofaro G, Muller H, Khan PM, et al. Surveillance in hereditary nonpolyposis colorectal cancer: an international cooperative study of 165 families. The International Collaborative Group on HNPCC. Dis Colon Rectum 1993; 36 (1): 1-4. 